\title{
EURASIAN BEAVER (CASTOR FIBER L.) POPULATION IN ASU SCIENCE AND TEACHING HUNTING AREA AND BEAVER DAMS REBUILD INTENSITY
}

\begin{abstract}
Monika RAŠKAUSKAITE், Institute of Forest biology and Silviculture, Faculty of Aleksandras Stulginskis University, Address: Studentų g. 9, Akademija Kaunas dist., Lithuania; monika.raskauskaite@asu.lt (corresponding author)

Kastytis ŠIMKEVIČIUS, Institute of Forest biology and Silviculture, Faculty of Aleksandras Stulginskis University, Address: Studentų g. 9, Akademija Kaunas dist., Lithuania; kastytis.simkevicius@asu.lt

Eurasian Beaver (Castor fiber L.) was reintroduced in Lithuania on 1947. Population growth was quite rapid ant there were about 6000 beavers on 1970. Nowadays beavers population in Lithuania is about 40 000. Beavers have a possibility to affect the environment where they live by building dams, lodges, making burrows systems, changing water level. Because of being such an active environmental former beaver has a huge indirect impact for forest and agricultural fields - higher water level usually causes damage for forest trees or crops. There are different studies about this beaver's ability to change environment and to build dams, lodges. Explanations why it is needed for this species now is clear, but still there are question how can these animal plan, organize and improve their ability to build. The aim of this research is to find out if dams rebuilt activity intensity differs during different year seasons and is it affected by the beaver's family size in current place. According to our findings, the beginning of dam rebuilt and total dam rebuild depends on year season - on fall season it takes 4 times less time. In addition to this, family size has an effect - bigger families rebuilt dams faster. Usually beavers do this job from midnight to 2 a.m. on fall season.
\end{abstract}

Keywords: Eurasian beaver, dam, rebuild, population

\section{INTRODUCTION}

Due to over-hunting Eurasian Beaver survived in eight relict populations in Europe and Asia (Nolet and Rosell, 1998). Until the XIX century the European Beaver was widespread in Lithuania but due to the high value of fur population of beaver rapidly decreased. In the beginning of 20th century there were no beavers permanently living in Lithuania (Prūsaite, 1988). Eurasian beavers have, since the late $19^{\text {th }}$ century, staged a remarkable recovery both in population and distribution (Halley et al., 2012). In Lithuania this species was reintroduced on 1947 by professor Tadas Ivanauskas. They were carried in from the Voronezh Reserve later on from the Gomel region. Also, after the Second World War beaver began to spread naturally from Belarus to Lithuania.

Nowadays the European beaver is a widespread rodent in Lithuania. According to the official statistics, there were 40.6 thousand beaver in Lithuania on 2017 (Lietuvos Respublikos..., 2017). According to other researchers, beaver in Lithuania is even more numerous. The average estimate density of the beaver sites in Lithuania is 4.12/1000 ha. Minimal estimated beaver site number in Lithuania is 22000 - 31000 (Ulevicius, 2008). A local beaver population investigated in hilly laky moraine uplands, reaching high density 19 beaver site / 1000 ha (Bluzma, 2003). Density of the beaver population was not even through the country. North-western, north-eastern and south-eastern parts of Lithuania were characterized by the highest density of beaver sites. Relatively low density of beaver sites was characteristic for some districts of northern, eastern and middle parts of Lithuania (Ulevicius, 2008).

Now it is known that the beavers are an important factor in the development of ecosystems, and there is one of the most important animals in renaturalizing the anthropogenic environment (Данилов, 2007). Beaver activities that impacts ecosystems can be grouped into two main groups. The first group includes the use and preparation of nutrients when trees and shrubs of varying sizes are cutting down. In this way beaver not only produce food but also creates a lot of dead wood that is not numerous in today's intensively managed forests (Andersson et. al, 2005). The second group of activities includes the constructions of beavers. The construction activity is divided into two subgroups: (1) construction of shelters (burrows systems, lodges) and (2) other structures for improving the living environment (dams and channels). Beaver activity can also have a direct and indirect impact on other components of biocenosis (Данилов, 2007).

Beavers have a unique ability to modify their environment by actively building dams. Dams are built to maintain a high and constant water level. Such a level of water is necessary for the safe and rapid movement of animals, for a food

Copyright (C) 2017 The Authors. Published by Aleksandras Stulginskis University. This is an open-access article distributed under the terms of the Creative Commons Attribution License (CC-BY 4.0), which permits unrestricted use, distribution, and reproduction in any medium, provided the original author and source are credited. 
rafting, safer direct access to the food and building materials, as well as high water level hide entrances to the burrows and lodges (Данилов, 2007). Typically dams are built in slowly floating rivers, streams, as well as in drainage ditches. Many scientists have studied the building activity of beavers (Hodgdon and Larson 1973; Żurowski, 1992; Hartman and Tornlov 2006; Pinto et al., 2009; Ulevicius et al., 2011). Żurowski (1992) reported that environmental conditions have an influence on building behaviour, as well as the type of construction (dam, lodge). Beavers built dams preferably in places where the sound of water floating over obstructions can be heard, and audible stimuli are considered an important factor in triggering the impulse to build a dam. Also building activity is determined by season (highest in autumn) (Hodgdon and Larson 1973), pregnancy and the presence of young individuals (Buech 1995). A dam-building behaviour is closely associated with beaver's habitat selection and dam-site selection (McComb, 1990, Hartman, 2006).

Enormous growth in the number of the beavers resulted in the corresponding increase of damage caused by them. Beavers can cause significant damage to forest or agricultural lands and transportation or hydrotechnical infrastructure. Analysis in 2004 and 2008 showed that beavers repeatedly most often inhabited canals of land reclamation (36\%), then natural streams, rivers, lakes and swamps (Ulevicius et. al, 2011).Higher water level in drainage ditches can cause damage by flooding forests or agricultural lands. Also beavers can dig burrows on drainage channel slopes, roadbeds or dams and thus erode them.

The aim of this research is to find out if dams rebuilt activity intensity differs during different year seasons and is it affected by the beaver's family size in current place. In order to find out answers to these questions state of beaver population has to be described. Objectives of the research are: (1) evaluate state of Eurasian Beaver population (linear density, active beaver sites density, beaver density and population abundance) and environment suitability for beavers living in Aleksandras Stulginskis Science and teaching hunting are; (2) identify beaver family size by precise method in order to select different size beaver families for the experiment; (3) investigate dams rebuilt intensity in different year season by different size beaver families (first sightings, time till the rebuilt starts, time necessary for the full dam rebuilt).

\section{RESEARCH METHODS}

Eurasian beaver was reintroduced on 1947 in Lithuania. Nowadays beaver population is dense enough (there were 40506 beavers in Lithuania according to wild animals census data (2017)) so beaver is one of game species in Lithuania. But attention to the protection of this species also is important. Limitation of hunting season is one of protection activities.

Research was carried out in Aleksandras Stulginskis University (ASU) Science and teaching hunting area which is located in central part of Lithuania (Fig. 1). This hunting area occupies 4608.3 ha. Forest consist $55.79 \%$ and water bodies $-40.68 \%$ of all territory. $72 \%$ of the hunting area is in Pravirsulis botanical - zoological reserve. Pravirsulis bog is fifth bog by the size in Lithuania.

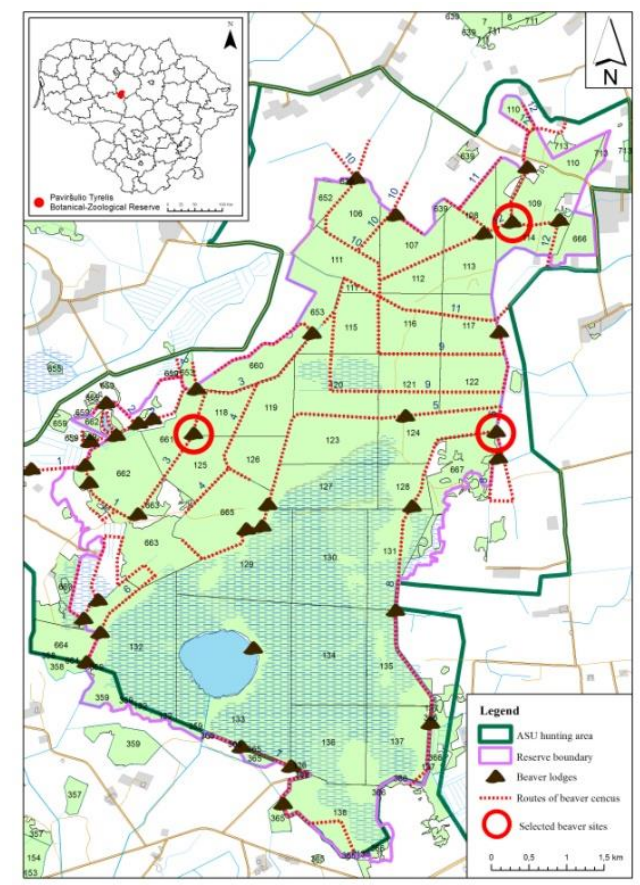

Figure 1. Research area

Hydrographical net in research area consists of lakes, rivers, forest drainage canals and bog. Water body suitability for beavers living was assed according to modified A. Mickus (1978) methodology (Table 1).

Beaver site is a territory occupied by beaver family or single beaver. This territory is defended from other beavers. Active beaver site - site where fresh beaver's activity signs (scrapings, dam building/reconstruction, lodges or burrows building/reconstruction, paths from the water, canals to scraping areas, winter food caches and others) are visible. Abandoned beaver sites were not included in the calculations. 
Table 1. Water body suitability for beavers living (Mickus, 1978)

\begin{tabular}{|c|c|}
\hline Average score & $\begin{array}{c}\text { Water body suitability for beavers living } \\
\text { (number of beavers) }\end{array}$ \\
\hline$>10$ & 8 \\
\hline $8-10$ & 5 \\
\hline $5-7$ & 2 \\
\hline Up to 4 & 0 \\
\hline
\end{tabular}

All active beaver sites in Pravirsulis botanical - zoological reserve were counted in all kinds of habitats. Linear density of beaver sites was calculated:

$$
T=\frac{N}{l} * 10,
$$

where: $\mathrm{T}$ - linear density of beaver's lodges (units/10 km), N - beaver sites number (units), 1 - length of hydrographical net $(\mathrm{km})$

Beaver sites density (number of beaver sites/1000 ha) was calculated, too.

Beavers family size in all active beaver sites was evaluated according to the modified A. Palioniene (1970) methodology (Table 2). Beaver population abundance (units) and density (units/1000 ha) were calculated.

Table 2. Beavers family size characteristics

\begin{tabular}{|l|l|}
\hline $\begin{array}{l}\text { Beavers } \\
\text { family size }\end{array}$ & Beavers living place characteristics \\
\hline One beaver & $\begin{array}{l}\text { On fall season scraped trees are rear. There are no winter food caches or only few branches in the water. Usually only } \\
\text { scraped branches are near the beavers lodge or 3-5 bigger trees. There are only few beaver paths from the water. No } \\
\text { youngsters scraping sings on trees. }\end{array}$ \\
\hline 2 beavers & $\begin{array}{l}\text { All activity is concentrated near the lodge. Usually there are 1 or 2 places of such a concentration. Paths from the } \\
\text { water are more actively used so they seams bigger. There are small winter food caches. No youngsters scraping sings } \\
\text { on trees. There are lots of scarped trees around the lodge; might be 3-5 places where scraped trees re concentrated. }\end{array}$ \\
\hline 3-5 beavers & $\begin{array}{l}\text { Winter food caches are in the water and they are noticeable easily. If beavers lodge is in the river, there might be few } \\
\text { dams near it. There are youngsters scraping sings on trees. }\end{array}$ \\
\hline $\begin{array}{l}5-7 \text { and } \\
\text { more } \\
\text { beavers }\end{array}$ & $\begin{array}{l}\text { There are lots of scraped trees and scraping usually is concentrated in big areas. Paths from the water usually are wide } \\
\text { and go to the scraping area. Winter food caches are big. In the rivers there is a system of dams. There are youngsters } \\
\text { scraping sings on trees. }\end{array}$ \\
\hline
\end{tabular}

Experiment of dams rebuilt intensity. Three different size beaver's families were selected for the dams rebuilt intensity experiment. Size of these selected families was evaluated by the more precise method - beaver's family size evaluation by the modified scrape up methodology (Feldhamer et al., 2017; Balciauskas, 2004).

All dams which belong for the selected beaver sites were counted and marked on the maps. Water level was evaluated and main dams identified. All dams were destroyed and special video cameras (Moultrie) were deployed near those dams which were most important for the water level in the specific beaver sites (main dams). No permits were necessary to deploy camera traps during this study. Camera settings were standardized over all cameras: the photo making regime of multiple photos with 1 second intervals was set.

Beaver dams destruction time. Dams were destroyed on the middle of April 2016. On this time beaver families are preparing for the new offspring and the last year youngsters must leave the parents' beaver sites in order to find out a new place for living. At this time water level is very important for the beaver families. After two weeks cameras information was checked and if the dam was rebuilt it was destroyed again and camera was left for two more weeks.

Second time of beaver's dams' destruction was on fall time. It was in the middle of October 2016. At this time beavers are preparing for the winter season and making winter food caches not too far from the beaver lodge or burrow. At this time water level also is very important for the beaver families.

During all experiment time beavers in selected beaver sites were not hunted.

\section{RESEARCH RESULTS}

State of beaver's population in Pravirsulis botanical - zoological reserve. Linear density of beaver sites in Pravirsulis botanical zoological reserve is 4.5 beaver sites $/ 10 \mathrm{~km}$. There are 27 active beaver sites where 73 beavers live. On the average there are 3 beavers /site (Table 3). Average beaver's number in one site is smaller than beavers monitoring (which was carried out in Lithuania on 2007) results -4 beavers/site (Ulevicius, 2008).

Active beaver sites density is 6 beaver sites $/ 1000$ ha. This number is higher if compare to beaver monitoring results -4.12 sites /1000 ha (Ulevicius, 2008). Beaver density in research area is 16 beavers /1000 ha. 
Table 3. Results of beaver population abundance investigation and water body suitability for beavers living evaluation

\begin{tabular}{|c|c|c|c|c|}
\hline $\begin{array}{c}\text { Length of the } \\
\text { route, } \mathrm{km}\end{array}$ & Number of beaver sites & Number of beavers & $\begin{array}{c}\text { Average number of } \\
\text { beavers in the site }\end{array}$ & $\begin{array}{c}\text { Score of suitability for } \\
\text { beavers living }\end{array}$ \\
\hline 9.6 & 4 & 10 & 3 & 6.68 \\
\hline 8.9 & 4 & 6 & 2 & 5.2 \\
\hline 14.7 & 7 & 25 & 4 & 7.6 \\
\hline 12.4 & 5 & 14 & 3 & 4.8 \\
\hline 14.5 & 7 & 18 & 3 & 6.1 \\
\hline
\end{tabular}

Most of detected beaver sites (59\%) are located in forest drainage ditches (Fig. 2).

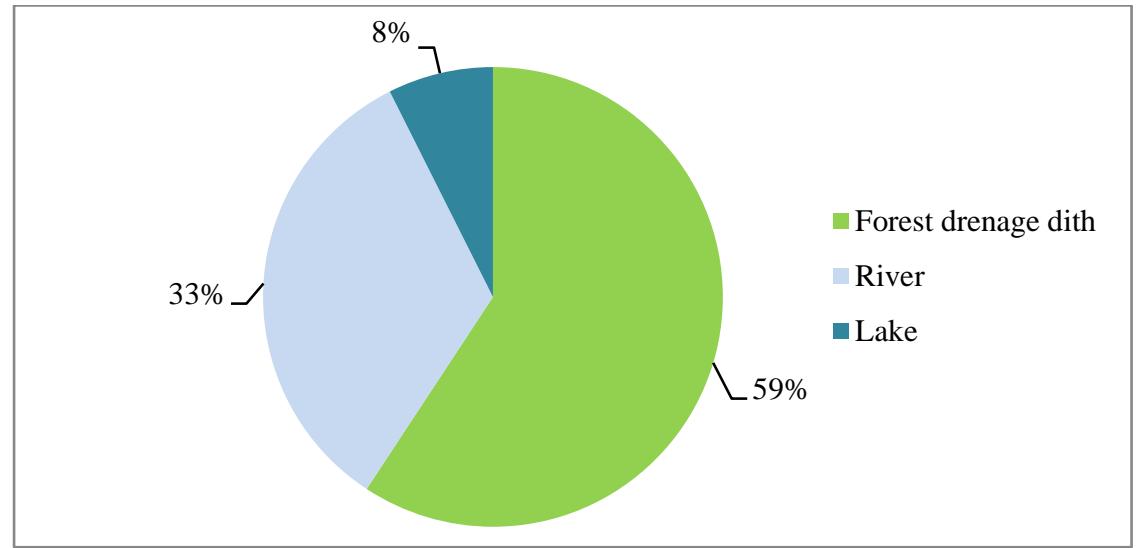

Figure 2. Beaver sites distribution in different type habitats

Evaluation of the environment suitability for beavers living shows, that in most cases (4 routes from 5) average score is between 5 and 7, that means that in the site might live not more than 2 beavers and only in one case the score is between 8 and 10, that means that in the site might live up to 5 beavers. Evaluation of the environment suitability for beavers living shows that maximum beaver number in the research area should not be higher than 59 beavers.

Beavers' dams rebuilt intensity. For the experiment 3 different family size beaver sites were selected (Table 4). Accurate beaver's family size was evaluated by the modified scrape up methodology (Feldhamer et al., 2017; Balciauskas, 2004).

Table 4 Number of days till the beavers started rebuilt destroyed dam

\begin{tabular}{|c|c|c|c|c|c|c|c|}
\hline \multirow{3}{*}{$\begin{array}{c}\text { No. of } \\
\text { beavers } \\
\text { site }\end{array}$} & \multirow{3}{*}{$\begin{array}{c}\text { Beavers } \\
\text { family size } \\
\text { (number of } \\
\text { beavers) }\end{array}$} & \multicolumn{6}{|c|}{ Days till the rebuild started } \\
\hline & & \multicolumn{3}{|c|}{ Spring time } & \multicolumn{3}{|c|}{ Fall time } \\
\hline & & $\begin{array}{c}\text { First dam } \\
\text { destruction }\end{array}$ & $\begin{array}{c}\text { Second dam } \\
\text { destruction }\end{array}$ & Average & $\begin{array}{c}\text { First dam } \\
\text { destruction }\end{array}$ & $\begin{array}{c}\text { Second dam } \\
\text { destruction }\end{array}$ & Average \\
\hline I & 2 & 6 & 2 & 4 & 2 & 1 & 1.5 \\
\hline II & 6 & 1 & 1 & 1 & 1 & 1 & 1 \\
\hline III & 4 & 4 & 12 & 8 & 1 & 3 & 2 \\
\hline
\end{tabular}

According to the experiment data, on fall time beavers stars to rebuild destroyed dams faster (Table 4). On the average it takes 4 times less time to begin dam rebuilt on fall time. This activity also depends on family size - the biggest family started rebuild fastest despite the season of the year. But there is the tendency that on fall time family size is not so important for the beginning of dam rebuilt.

It takes time to rebuild the dam. On spring time it takes on average 5.5 days and on fall time -3 days (Table 5). Family size is not so important for the dam full rebuilt time on fall season - all the families rebuild dams fully during 3 day on average.

Table 5 Number of days which is necessary to rebuilt beavers dam fully

\begin{tabular}{|c|c|c|c|c|c|c|c|}
\hline \multirow{3}{*}{$\begin{array}{c}\text { No. of } \\
\text { beaver } \\
\text { site }\end{array}$} & \multirow{3}{*}{$\begin{array}{l}\text { Beaver } \\
\text { family } \\
\text { size } \\
\text { (number } \\
\text { of } \\
\text { beavers) }\end{array}$} & \multicolumn{6}{|c|}{ Days required for the full rebuild of the dam } \\
\hline & & \multicolumn{3}{|c|}{ Spring time } & \multicolumn{3}{|c|}{ Fall time } \\
\hline & & $\begin{array}{c}\text { First dam } \\
\text { destruction }\end{array}$ & $\begin{array}{c}\text { Second dam } \\
\text { destruction }\end{array}$ & Average & $\begin{array}{l}\text { First dam } \\
\text { destruction }\end{array}$ & $\begin{array}{c}\text { Second dam } \\
\text { destruction }\end{array}$ & Average \\
\hline I & 2 & 9 & 16 & 12.5 & 3 & 4 & 3.5 \\
\hline II & 6 & 2 & 1 & 1.5 & 2 & 4 & 3 \\
\hline III & 4 & 1 & 4 & 2.5 & 2 & 3 & 2.5 \\
\hline
\end{tabular}

Daytime when the first beaver shows up near the dam was registered, too. During both year seasons beavers are most active from midnight till 1 a. m. (Fig. 3 and 4). 


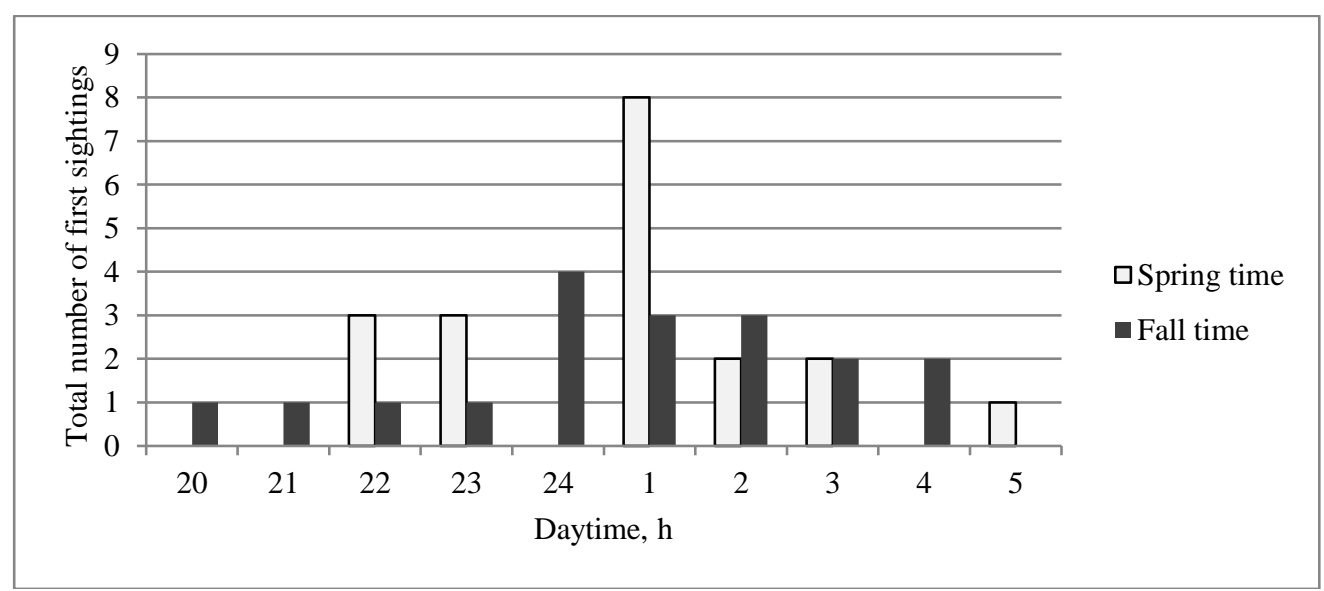

Figure 3. Day time when beavers activity of dam rebuilding starts

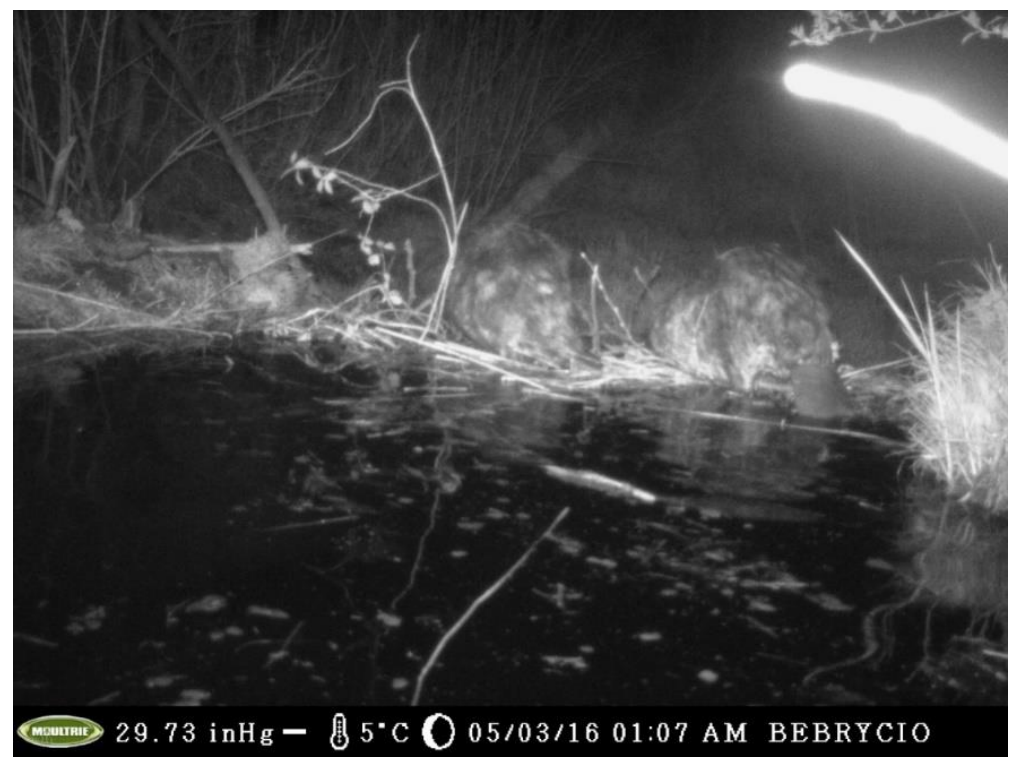

Figure 4 . Two beavers on the dam

Beaver's activity on fall season starts earlier (from 20.00) then on spring season (22.00). On spring season beavers are more active till midnight. Contrary on fall season - higher activity is noticeable after midnight at this time.

\section{CONCLUSIONS AND DISCUSSIONS}

In conclusion, beaver's population in Pravirsulis botanical-zoological reserve has good living conditions so beaver's density is higher than it should be according to environmental conditions suitability for beavers living evaluation results. According to consensus data there are 27 active beaver sites and 73 beavers in Aleksandras Stulginskis University Science and teaching hunting area and the environmental conditions suitability for beavers living evaluation results show that this number should be not more than 59 beavers in this area. Active beaver sites density ( 6 beaver sites $/ 1000$ ha) is higher than mean beaver site density in Lithuania (4.12 beaver sites /1000 ha). Linear density of beaver sites $(4.5 / 10 \mathrm{~km})$ is higher than in research by Ulevičius et al., (2009) $(2.1$ sites $/ 10 \mathrm{~km})$. These data show that hunting pressure on beaver might be harder.

Beaver sites in Aleksandras Stulginskis University Science and teaching hunting area are usually situated in floating water bodies (59\% of all cases) so dams are necessary for beavers living. According to Bau (2001), beavers spent about $12 \%$ of all time budgets on dam building and in $24 \%$ of all cases it is the first behavior to be performed after first sightings. Our research shows, that most of fist sightings of beavers are from midnight to 01.00. Active period of beaver identified in different researches is $20.00 \mathrm{~h}$ to $07.00 \mathrm{~h}$ (Bau, 2001; (Graf et al., 2016) with a peak from $23.00 \mathrm{~h}$ to $03.00 \mathrm{~h}$ (Swinnen et al., 2015). Mentioned results correspond to our research results - beavers in most cases started their dam building activity from midnight till 01.00. It is proved that beavers activity depends on night length, darkness of the night and year season (Swinnen et al., 2015; Buech 1995). The time allocated to different behavioral states differs during the day. Dam building is most active from 22.00 till midnight and from 04.00 till 06.00 (Bau, 2001). Our results also showed that dams rebuilt after the destruction depends on year season. On fall time beavers start dams rebuilt earlier and rebuilt dams fully faster than on spring time. 


\section{Proceedings of the $8^{\text {th }}$ International Scientific Conference Rural Development 2017}

Our experiment result that beaver's family size affects the rebuilt of dam rebuilt intensity on spring season but not on fall season corresponds to other researches, too. Buech (1995) proved that sex of beavers is important for time budges allocation - males spent more time on construction than females and that time budget allocation to different activities differs in year season. Similar results were presented by the (Hodgdon and Larson 1973).

\section{REFERENCES}

1. Andersson, L, Klriukelis, R., Skuja, S. 2005. Kertinių miško buveinių inventorizacija Lietuvoje. Vilnius, p. 135. [In Lithuanian]

2. Balciauskas, L.2004. Methods of land ecosystems research. Part I. Animals census methods. Vilnius. P. 184.

3. Barnes D. M. 1997. Habitat Factors Influencing Beaver Dam Establishment in a Northern Ontario Watershed. The Journal of Wildlife Management, Vol. 61, Iss. 4, pp. 1371-1377. https://doi.org/10.2307/3802140

4. Bau, L., M. 2001. Behavioural ecology of reintroduced beavers (Castor fiber) in Klosterheden State Forest, Denmark. Master thesis. University of Copenhagen, p. 67.

5. Bluzma P. 2003. Beaver abundance and beaver site use in a hilly landscape (Eastern Lithuania). Acta Zoologica Lituanica, Vol. 13, No. 1, pp. 8-14.

6. Buech, R. R. 1995. Sex differences in behavior of beavers living in near-boreal lake habitat. Canadian Journal of Zoology, Vol. 73(11), pp. 2133-2143. https://doi.org/10.1139/z95-250 .

7. Feldhamer, G., Carlyle Thompson, B., A. Chapman, J. 2017. Wild mammals of North América: Biology, management, and conservation. Ed. by George A. Feldhamer, Bruce C. Thompson and Joseph A. Chapman@. SERBIULA (sistema Librum 2.0)

8. Graf, P. M., Hochreiter, J., Hackländer, K., Wilson, R. P., Rosell, F. 2016. Short-term effects of tagging on activity and movement patterns of Eurasian beavers (Castor fiber). European Journal of Wildlife Research, Vol. 62(6), pp. $725-736$. https://doi.org/10.1007/s10344-016-1051-8

9. Halley, D., Rosell, F., Saveljev, A. 2012. Population and distribution of Eurasian Beaver (castor fiber). Boltic Forestry, Vol. 18(1), pp. 168-175.

10. Hartman, G.andTornlov, S. 2006. Influence of watercourse depth and width on dam-building behaviour by Eurasian beaver (Castor fiber). Journal of Zoology, Vol. 268(2), pp. 127-131. https://doi.org/10.1111/j.1469-7998.2005.00025.x

11. Hodgdon, H. E., Larson, J. S. 1973. Some sexual differences in behaviour within a colony of marked beavers (Castor canadensis). Animal Behaviour, Vol. 21(1), pp. 147-152. https://doi.org/10.1016/S0003-3472(73)80052-1

12. Lietuvos Respublikos Aplinkos ministerija. 2017. Census of game species 2017 (2017 m. medžiojamųjų žvèrių apskaita). Available at http://www.am.lt/VI/index.php\#a/18447 [In Lithuanian]

13. McComb, W.C., Sedell, J.R., Buchholzet, T.D. 1990. Dam-site selection by beavers in an eastern Oregon basin. Great Basin Naturalist, Vol. 50, No. 3, pp. 273-281.

14. Mickus, A. 1978. Effect of biotope traits to beaver population abundance and territorial distribution. Final report. Laboratory of teriology. Vilnius.

15. Nolet, B. A.andROSELL, F. 1998. Comeback of the beaver Castor fiber: An overview of old and new conservation problems. Biological Conservation, Vol. 83(2), pp. 165-173. https://doi.org/10.1016/S0006-3207(97)00066-9

16. Palioniene, A. 1970. European beaver (Castor fiber), beaver reaclimatisation in TSR Lithuania and use of it utilization. $\mathrm{PhD}$ thesis. Vilnius University. Vinius.

17. Pinto, B., Santos, M. J., Rosell, F. 2009. Habitat selection of the Eurasian beaver (Castor fiber) near its carrying capacity: An example from Norway. Canadian Journal of Zoology, Vol. 87(4), pp. 317-325. https://doi.org/10.1139/Z09-015

18. Prūsaitė J. 1988. Lietuvos fauna. Žinduoliai. Vilnius, p. 293. [In Lithuanian]

19. Swinnen, K. R.R., Hughes, N. K., Leirs, H. 2015. Beaver (Castor fiber) activity patterns in a predator-free landscape. What is keeping them in the dark? Mammalian Biology - Zeitschrift für Säugetierkunde, Vol. 80(6), pp. 477-483. https://doi.org/10.1016/j.mambio.2015.07.006

20. Ulevicius, A. 2008. State of European beaver (Castos fiber) population in Lithuania. Report of scientific research. Vilnius. P. 52.

21. Ulevicius, A., Jasiulionis, M., Jakstiene, N., Zilys, V. 2009. Morphological alteration of land reclamation canals by beavers (Castor fiber) in Lithuania. Estonian Journal of Ecology, Vol. 58(2), 126. https://doi.org/10.3176/eco.2009.2.06

22. Ulevicius, A., Kiselyte, N., Jasiulionis, M. 2011. Habitat use and selectivity by beavers (Castor fiber) in anthropogenic landscape. Ekologija, Vol. 57(2). https://doi.org/10.6001/ekologija.v57i2.1884

23. Żurowski W. 1992. Building activity of beavers. Acta Theriologica, Vol. 37, p. 403-411. https://doi.org/10.4098/AT.arch.92-41

24. Данилов П.И. et al. 2007. Речные бобры Европейского севера России. Москва. [In Russian] 